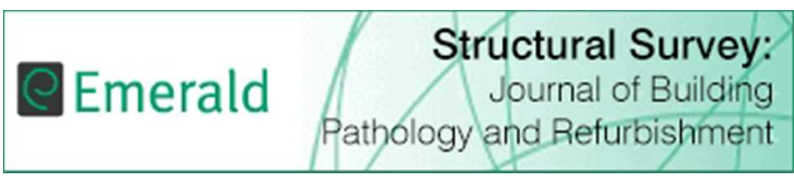

\title{
Technical considerations in green roof retrofit for stormwater attenuation in the Central Business District
}

\begin{tabular}{|r|l|}
\hline Journal: & Structural Survey \\
\hline Manuscript ID: & SS-07-2014-0031.R1 \\
\hline Manuscript Type: & Original Article \\
\hline Keywords: & $\begin{array}{l}\text { green roof, retrofit, central business district, office buildings, Australia, } \\
\text { water sensitive urban design (WSUD) }\end{array}$ \\
\hline \multicolumn{2}{|l}{} \\
\hline
\end{tabular}

SCHOLARONE

Manuscripts 


\section{Technical considerations in green roof retrofit for stormwater attenuation in the Central Business District}

\section{Introduction}

The 2013 Inter-governmental Panel on Climate Change (IPCC) Report has concluded that, to date, efforts to slow down anthropocentric induced changes to climate have had little or no effect (IPCC, 2013). Predictions vary for different countries with Australia estimated to become hotter and dryer but with increased heavy rainfall in places. Coupled with this, is an increase in urban densification and population, with less permeable space available in urban settlements (Wheater and Evans, 2009, White and Howe, 2002, Jha et al., 2011). For most developed countries the overwhelming percentage of stock that currently exists will be around in 2050 (Kelly, 2008), and consequently a significant impact to mitigate climate change lies with retrofit and adaptation of the existing stock (Dixon and Eames, 2014).

Around $40-50 \%$ of surfaces in cities are rooftops (Dunnet and Kingsbury, 2004), which are predominantly unused. It is possible to retrofit some of these roofs with green roof technology. In a Melbourne study Wilkinson and Reed (2009) concluded 15\% of office roofs were suitable for retrofit with intensive green roofs. There are various types of green roof design depending on their intended purpose. For example, some green roofs may be designed for thermal performance whilst others may be designed for stormwater reduction (Castleton et al, 2010).

Green roof retrofit is a relatively new area of practice for built environment professionals and stakeholders. The key aspects that built environment professionals need to consider when evaluating roofs for the purpose of green roof retrofit for stormwater attenuation and also when assessing green roofs for technical due diligence purposes are outlined. Although green or sod roofs have been built over many centuries, contemporary roofs adopt new approaches and technologies. By 2003 Herman in Castleton et al (2010) stated that 14 per cent of all flat roofs in Germany were green roofs and that the numbers were increasing. Although the authors acknowledge that there are many benefits of green roofs such as improved thermal performance and enhanced bio-diversity this study is focussed on retrofit for stormwater attenuation and flood risk alleviation. The research questions addressed here are; what are the perceived technical issues stakeholders and built environment professionals need to consider with green roof retrofit for stormwater attenuation? And, what is the perceived awareness of the economic, social and environmental aspects of green roof retrofit?

\section{Types of green roofs}

A green roof uses plants, ranging from grasses, mosses, lichens, sedums, trees, shrubs, flowers and bushes (Weiler and Scholz-Barth, 2009). Green roofs are also called eco-roofs, nature roofs or roof greening systems. In short green roofs are a living vegetated roofing alternative to traditional impervious roofing materials comprising the following:

- a roof structure;

- a waterproof membrane or vapour control layer;

- insulation (i.e. if the building is heated or cooled);

- a root barrier to protect the membrane (i.e. made of gravel, impervious concrete, polyvinylchloride (pvc), thermoplastic polyolefin (tpo), high-density polyethylene (hdpe or copper);

- a drainage system;

- a filter cloth (non-biodegradable fabric);

- a growing medium (soil) consisting of inorganic matter, organic material (straw, peat, wood, grass, sawdust) and air;

- and, plants.

Broadly green roofs are extensive or intensive (see plate 1 and 2) and a simple typical cross section is shown in figure 1. Extensive green roofs can provide space for people and the depth of soil or substrate 
layer provided varies between 50 to $200 \mathrm{~mm}$ and requires artificial irrigation. Intensive roofs often require a deeper planting medium greater than $150 \mathrm{~mm}$. A third type; a semi intensive green roof, is a hybrid of the intensive and extensive roofs. It is vital to keep the plants alive in the long-term and this is a challenge because it requires an active and ongoing commitment to a maintenance and an irrigation, or watering, regime.

Plate 1 Foss Street Sydney - extensive green roof

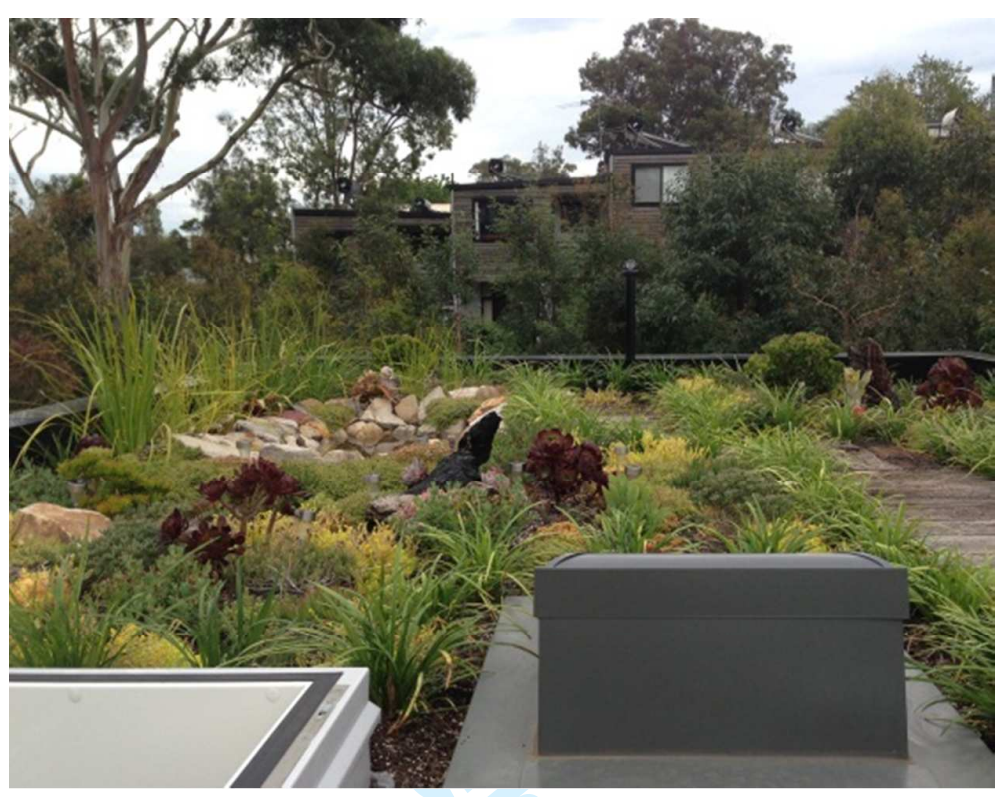

(Source; Lucy Sharman Green Roofs and Green Walls Project Officer City of Sydney)

Plate 2 Wharf Terrace Wooloomolloo Sydney - intensive green roof

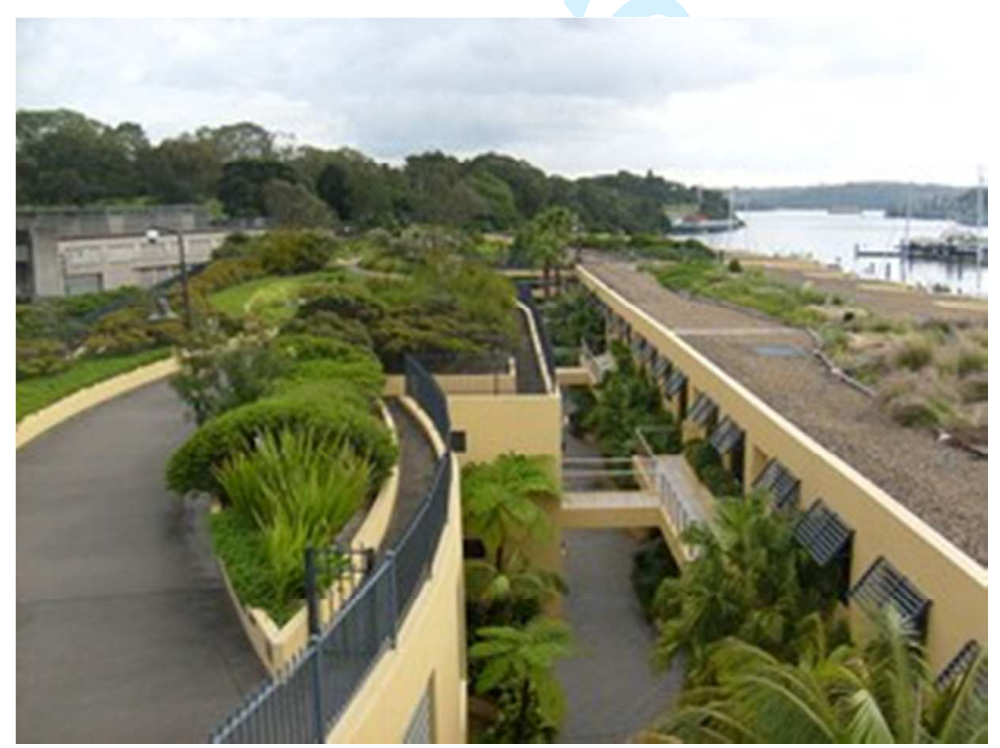

(Source; Lucy Sharman Green Roofs and Green Walls Project Officer City of Sydney) 
Figure 1 Typical green roof cross section

\section{Table 1: Attributes of extensive and intensive green roofs}

\begin{tabular}{|l|l|}
\hline Extensive green roof & Intensive green roof \\
\hline Shallow growing medium $(<150 \mathrm{~mm})$ & Deeper growing medium $(>150 \mathrm{~mm})$ \\
\hline Lightweight structure to support roof & Heavier roof structure required to support roof \\
\hline Cover large expanses of rooftop & Small trees and shrubs feature \\
\hline Requires minimum maintenance & More maintenance required \\
\hline Lower capital cost & More expensive \\
\hline Not usually recreational & More common in tropical climates \\
\hline Accessible or inaccessible & Accessible or inaccessible \\
\hline Does not usually require irrigation & \\
\hline $\begin{array}{l}\text { Minimum structural implications for existing } \\
\text { buildings }\end{array}$ & \\
\hline
\end{tabular}

(Source: Author)

Green roof stormwater performance varies depending on location and climate (Stovin et al., 2012). Modelling the reduction in runoff on stormwater roofs in Brussels, Belgium through green roof retrofit showed that typical traditional non green roofs experienced between 62\% to 91\% run-off (a median of $85 \%$ ). On the other hand intensive green roofs experienced run-off between 15\% and 35\% (median 25\%) and extensive green roofs experienced run-off of 19\% - 73\% (median 55\%). Significantly the runoff was much lower in warmer summer months, some $80 \%$ winter runoff versus $52 \%$ summer run-off for green roofs compared to $86 \%$ winter and $70 \%$ summer run-off for gravel roofs. This is largely because during the wetter winter periods roofs become saturated and are unable to absorb much additional rainfall (Mentens et al, 2006). Similarly green roofs designed for thermal performance, for reduction in urban heat island, food production or for bio-diversity will have difference performance based on location, climate and other variables (Fioretti et al, 2010. MacIvor and Lundholm, 2011). 
Green roofs can help reduce the risk of urban flooding when used as part of measures designed to restore, or mimic, natural infiltration patterns; by decreasing runoff volumes and attenuating peak flows. Within business districts, this approach could involve the wide spread retrofit of green roofs, permeable paving and other surface or near-surface drainage options (Charlesworth and Warwick, 2011). Infiltration and storage devices, such as permeable paving, can be employed around commercial premises to reduce runoff, whilst green roofs and rainwater gardens can absorb rainwater, thereby attenuating peak flows. Urban renewal or refurbishment provides an opportunity for such retrofitting initiatives: in the US this approach has been adopted in both New York (NYC Environmental Protection, 2011; NYC

Environmental Protection, 2012) and Portland, Oregon. In the latter case, in order to increase the uptake of green roofs and disconnection of downspouts, financial incentives were offered (Environmental Services - City of Portland, 2006; Environmental Services - City of Portland, 2011). Doubts have, however, been raised as to whether widespread retrofit is a viable option structurally or functionally (Wilkinson and Reed, 2009); furthermore, the contribution to cost effective reduction of flood risk from property level adaptation is yet to be fully explored (Lamond and Proverbs, 2009; Joseph et al., 2012).

\section{Technical considerations}

The suitability of an existing building for a green roof retrofit depends on factors such as the roof type, size and slope. The roof structure and roof covering influence the type of green roof that may be retrofitted, for example the load-bearing capacity of the structural form. Roofs on mid-sized and larger commercial buildings in the UK and Australia tend to have concrete slab construction which may be able to bear green roof loads. A typical load for an extensive green roof structure varies between 1.6-2.4 $\mathrm{kN} / \mathrm{m}^{2}$ and for intensive green roofs from 2 to $15 \mathrm{kN} / \mathrm{m}^{2}$ (Andras, 2010). Castleton et al (2010), in their retrofit of a green roof in Sheffield England, stated 'the concrete slab had an estimated capacity of 8-10 $\mathrm{kN} / \mathrm{m} 2$, enough to support a substrate depth up to $800 \mathrm{~mm}$ ', though they do not state the thickness of the slab nor the span. Depending on the structural load bearing capacity of the existing roof, a lightweight growth media and additional structural support may be required so as not to overload the structure.

Furthermore the intended use of the roof, as well as size, is an issue for example; is public or user access possible or desirable for a recreational green roof? The roof may be too small to warrant the cost of the work to retrofit. In 2008, a typical cost per metre squared for a sophisticated residential green roof in New York ranged from $\$ 269$ to $\$ 1075$ (GreenBuildings.Com, 2014). Table 2 sets out costs for UK green roofs with areas ranging from 100 to $1000 \mathrm{~m}^{2}$. Whilst the rates for new build include the specialist contractor's costs, the main contractors' preliminaries, overheads and profit costs are excluded. These costs were current in June 2006 based on an average UK location and some adjustments would be required for 2014 rates and for retrofit. These figures illustrate the amount of variability in costs for green roofs based on different specifications. It is also possible other remedial works may be triggered, such as upgrading access is required, and this renders the project prohibitively expensive compared to the final overall benefit gained.

Table 2 Indicative costs of green roof UK 2006

\begin{tabular}{|l|l|}
\hline Sedum blanket only & $\AA^{35-40 / \mathrm{m}^{2}}$ \\
\hline Sedum blanket with drainage layer and filter fleece & $\AA^{45-65 / \mathrm{m}^{2}}$ \\
\hline Sedum blanket on filter fleece and drainage layers, capping layer and vapour barrier & $£, 80-115 / \mathrm{m}^{2}$ \\
\hline Extra for insulation & $\AA^{50 / \mathrm{m}^{2}}$ \\
\hline Extra for waterproof membrane and vapour barrier & $£^{30-45 / \mathrm{m}^{2}}$ \\
\hline $\begin{array}{l}250 \mathrm{~mm} \text { thick growing medium on drainage board, root membranes and insulation; } \\
\text { turf }\end{array}$ & $£^{85-100 / \mathrm{m}^{2}}$ \\
\hline $\begin{array}{l}225 \mathrm{~mm} \text { thick growing medium on filter fleece and LDPE drainage core; plug and } \\
\text { hydro-seed planting }\end{array}$ & $f^{50-60 / \mathrm{m}^{2}}$ \\
\hline
\end{tabular}

(Source Willmot Dixon, 2010) 
When considering the budget and how much an owner is willing to pay, a whole life cycle costing approach may be useful to determine the overall costs and may offset a higher initial construction and installation costs with some buildings in some locations a green roof may add to capital and rental value and to environmental ratings (Wilkinson and Reed, 2009). Alternatively considerations of multiple benefits to the wider community may be reflected in reputational benefits or direct incentive schemes (Lamond et al., 2014 ).

Extensive and intensive green roofs require a minimum slope of $2 \%$ and green roofs with less than a $2 \%$ slope require additional drainage measures to avoid water logging (University of Florida, 2008). Additional requirements include good drainage and waterproofing. Conversely, while a steeply pitched roof may be amenable to green roof retrofit the slope will have consequences on the stormwater performance (Czemiel-Berndtsson, 2010).

In some locations the capacity for rainwater harvesting and the use of drought or heat tolerant plants is desirable to cope with fluctuations in climate. Planting should also be established with levels of maintenance in mind (Castleton et al, 2010. Williams et al, 2010). Furthermore some roofs have a water supply whereas others do not, and this is an issue where watering and irrigation of plants is required, as it too can add to the total costs of retrofit.

The stormwater retention qualities of green roofs depend upon the depth of the substrate and other variables, including: slope (Getter et al., 2007); exposure; prevailing wind conditions; the absorbency of the substrate and its water retention qualities; and the amount of evaporation (which varies according to external temperatures and humidity) (Blanc et al., 2012). The surveyor has to identify the additional loads the existing roof may safely bear, including the weight of retained water, and evaluate the design to ascertain how much reduction in runoff might be achieved.

The orientation of the roof affects the amount of exposure to sun the roof will get and this affects the type of plants which will flourish there (Wilkinson and Reed, 2009). Added to this the surveyor also needs to consider any overshadowing from surrounding buildings as this affects access to sunlight for the plants. Finally the height above ground will affect exposure levels to high winds in particular. Some rooftop environments can be hostile in different seasons and planting specifications must take this into account (Williams et al, 2010).

The longevity of the structure, drainage and waterproofing system is essential because replacement costs are high. Green roofs can be designed to last over 50 years (Porsche and Köhler, 2003); approximately twice the life cycle of a roof covering such as bituminous felt and on this basis may present a good economic argument for installation. Where an existing roof covering is approaching the end of its useful life, it may be opportune and cost effective over a 50 year life cycle to retrofit. Overall the following criteria are taken into account when determining whether a roof is suitable for retrofitting:

- load bearing capacity of the roof,

- roof pitch,

- water supply for irrigation,

- preferred planting,

- orientation of the roof,

- height above ground,

- sustainability of components; and,

- levels of maintenance.

Whilst the first six criteria are physical attributes of buildings, the last two are related to building owner and/or client desires and the ability to maintain the green roof. Owners, property managers and facility managers need to consider the maintenance requirements. Long-term maintenance is essential and a minimum five year maintenance contract is recommended to ensure the correct processes are undertaken and that planting is properly established. Maintenance requirements vary depending on the type of roof provided. All green roof types will have variable water retention characteristics which will also vary depending on their location, orientation and exposure. Roofs designed for stormwater retention should 
have enhanced water absorption qualities. Table 3 summarises the technical features surveyors need to be consider.

Table 3 Technical Features for Green Roofs

\begin{tabular}{|ll|}
\hline 1. & Position of the building. \\
2. & Location of the building. \\
4. & Orientation of the roof. \\
5. & Amount of overshadowing (if any). \\
6. & Roof type. \\
7. & Roof pize. \\
8. & Load-bearing capacity $\left(\mathrm{kN} / \mathrm{m}^{2}\right)$. \\
9. & Drainage and waterproofing system. \\
10. & Condition of the existing membrane. \\
11. & Access to the roof for construction and user (if accessible to users). \\
12. & Weight of substrate and planting. \\
13. & Water supply. \\
14. & Preferred planting. \\
15. & Levels of maintenance desired. \\
\hline
\end{tabular}

(Source: authors)

\section{Research Methodology}

This is qualitative research, collected in the form of words, which seeks to ascertain stakeholder views and perceptions with regards to the technical issues around green roof retrofit (Silverman, 2013). The first stage is to identify and evaluate key stakeholder issues. Stakeholders from the design, construction and property management professions as well as government stakeholders from the City of Sydney and State agencies attended the two focus groups held on the 14th June 2012 to discuss issues with regards to the design, construction and management of green roofs. Participants were asked to discuss the perceptions of the issues such as barriers and opportunities in construction and design, in property management and maintenance and in property marketing. The focus group discussion also covered issues of incentivisation or mandation as well as identifying the key social, environmental or economic barriers and drivers for green roof projects (see Appendix 1 Focus Group discussion guide).

The focus groups lasted 2 hours each and 15 participants attended in total. The views and perceptions were collected via recordings. Focus groups were adopted as a means of exploring the various nuances of views expressed by experienced professionals in real time. Recording the focus groups ensured a good flow of ideas and views (Silverman, 2013). Best practice guidelines were followed in respect of focus group procedures to ensure all participants had the opportunity to express their views (Silverman, 2013). The focus groups comprised an open structured discussion, during which participants were asked to participate in an attitudinal scale exercise where they indicated on a horizontal scale how much they agreed or disagreed with various statements in respect of green roofs as shown in the discussion guide. Following the focus groups participants were offered the opportunity to provide additional comments and feedback. Six participants were then interviewed through a semi structured in depth interview to gain deeper insights into their perceptions. These participants were from local government, the green roof industry, academia, real estate and construction companies.

\section{Data interpretation and findings}

One of the key technical issues raised by the focus group participants was the waterproofing systems and the reliability of roof membranes, which was also a finding in the Koehler study (2003). Furthermore the 
load bearing capacity of existing roofs was raised especially with respect to intensive green roofs, confirming concerns expressed by Stovin et al (2007). Although the experience of retrofitting a Sheffield roof demonstrated that a typical concrete roof slab of $8-10 \mathrm{kN} / \mathrm{m}^{2}$ could support a substrate of up to 800 $\mathrm{mm}$ depth (Castleton et al 2010) and therefore it is possible these perceptions may be erroneous in many cases. As one of the interviewees who works for a developer stated; "We looked at one of the buildings in the CBD and one of the main problems was having to upgrade the existing roof to take the weight". Further education may increase knowledge and awareness, particularly if case study examples demonstrate the load bearing capacity of existing roof structures in green roof retrofit.

Another technical issue raised was irrigation or watering systems, the benefits of automated irrigation so that manual maintenance is not required. The technology for automated watering systems is relatively simple to design and install and not inordinately expensive. The careful specification of planting can greatly affect the amount of watering required, for example drought tolerant plants require less water than other species (Williams et al, 2010). The challenge of designing for the Australian climate was raised and the need to specify plants for longevity; however it seems that specifying indigenous species could overcome this issue to a great extent. Interestingly although participants were aware that native species were drought tolerant and able to survive the variations in the Australian climate, they also held the belief that the 'public' expected green roofs to be lush and verdant. Clearly there is a mismatch between expectations of planting and what is most likely to flourish and survive in the Australian climate. It was agreed that public education programs would be needed to align expectations where bio-diversity roof were planted with native species.

Allied to technical issues and, in terms of encouraging greater take up in the property industry, a high degree of influence was perceived to rest with designers who may specify green roofs at the outset of a project. However it is also the case that, many new build projects have included green infrastructure at the commencement of the project only to have it 'value engineered' out of the specification at a later stage when cost savings were required. On this basis it is apparent that key stakeholders needed to champion the green roof throughout the project planning stage. One of the interviewees stated that "architects are speciffing almost every project now has some form of green bling ....ultimately it is up to the client and developer - whether it gets value engineered out, Builders are often quite risk averse." If green roofs are perceived as mere 'bling'; it is not surprising they get dropped from projects.

The final issue was the knowledge and expertise required of designers and specifier's and contractors. With little local experience of green roof design and specification to date in Australia, stakeholders were taking a risk averse position as a result of their own lack of experience. The skills base of the industry was also discussed with concerns around the availability of appropriately skilled and qualified specialists, particular with regards to waterproofing systems. Specifically there was concern regarding acceptance of lowest tenders which might involve less reliable products and lower skilled operatives. The problem of accepting the lowest tender is not unique to green roof retrofit and is a risk affecting all aspect of the construction stage of projects (Kelly et al, 2002). On the other hand, product innovation and development was an opportunity that arises out of this concern and was acknowledged by participants. Also related to the concern about products and workmanship, was the view that modular systems could be a cost effective practical alternative which may reduce the concern about leaks resulting from green roof installation. To date little practical examples exist in Australia from which to draw on.

With regards to maintenance and upkeep, again the risk of roof leaks and longevity of the membranes were key concerns to participants and was acknowledged in Koehler's study (2003). It appears that the perception of a potential maintenance liability deters some practitioners rather than direct personal experience of green roofs as another interviewee stated "you can design out leak risk - it's worksmanship issues". Maintenance of irrigation systems was also raised where some had knowledge of green roofs which had died off due to lack of irrigation and maintenance, with significant additional costs incurred to replant the roof. Table 4 summarises the technical issues of concern to stakeholder with respect to green roof technology and also the issues where no awareness was demonstrated. 
Table 4 Green roof retrofit technical issues and stakeholder awareness

\begin{tabular}{|l|l|l|}
\hline Technical issue & Identified & $\begin{array}{l}\text { Not } \\
\text { identified }\end{array}$ \\
\hline Type of membrane & X & \\
\hline Planting survival & X & \\
\hline Watering / irrigation & X & \\
\hline Planting specification for Australia & X & \\
\hline Load bearing capacity of existing roof & X & \\
\hline Automated watering system & X & \\
\hline Knowledge of designers and installers & X & \\
\hline Skill base of installers and workmanship & $\mathrm{X}$ & \\
\hline Opportunity for product innovation and development & $\mathrm{X}$ & \\
\hline Maintenance & $\mathrm{X}$ & \\
\hline Difference/ distinction between intensive and extensive roofs & & $\mathrm{X}$ \\
\hline Condition of existing membrane for retrofit & & $\mathrm{X}$ \\
\hline Access for construction and users & & $\mathrm{X}$ \\
\hline Awareness of climatic variations & & $\mathrm{X}$ \\
\hline Adoption of whole life costing approaches & & $\mathrm{X}$ \\
\hline Influence of roof slope & & $\mathrm{X}$ \\
\hline Availability of water supply to roof & & $\mathrm{X}$ \\
\hline Substrate qualities & & $\mathrm{X}$ \\
\hline Exposure, orientation and overshadowing & $\mathrm{X}$ \\
\hline Source: Authors) & \\
\hline
\end{tabular}

(Source: Authors)

Where economic aspects were considered, there were perceptions that green roofs were expensive. As noted above green roofs were often value engineered out of designs on the basis that they are perceived as a luxury 'add on' rather than an integral part of the design contributing to environmental sustainability. It was acknowledged that greater specification of green roof will deliver economies of scale and reductions over time. However this needed to be set against the risk of cost cutting or suppliers entering the market with substandard or poor quality products. It was considered important that sufficiently skilled and qualified installers were able to meet market demand at a reasonable cost. The costs of maintenance were related to the purpose of the roof. For example where public access was provided a greater maintenance requirement was perceived to exist, however the social benefits would be high though much harder to quantify. The difficulties of quantifying social benefits is on-going. Costs were also considered in respect of initial costs and the ongoing maintenance and management costs.

The environmental drivers for green roofs, such as urban heat island, bio-diversity and food production were perceived as less important than economic and social drivers by the participants. This is probably because practitioners focus on individual projects rather than city wide issues such as UHI and biodiversity. Although they did concede that as climate change and environmental factors became more pressing on the future this would change. The perception of existing wildlife in the city was that it comprised 'rats, ibises and pigeons'; a negative and limited assessment. Food production was considered impractical on any scale although it was acknowledged that some hotel and restaurants did produce some food on their rooftops. Furthermore some participants knew of bee hives producing honey on CBD 
roofs. It was considered that large flat roofs typically found on industrial property were more suited to food production. Where the UHI was concerned participants believed that not enough roofs were yet greened to make a difference to the UHI and that UHI was not a strong driver for green roof specification. This view is supported by the literature (Castleton et al, 2010) and it may be that regulation is required if reduction of the UHI is the rationale for specification of green roofs in Sydney. Green roofs were perceived as providing 'green bling' to some extent in developments, which undermines the environmental and social benefits that they provide. Practitioners also felt other measures could deliver energy savings on a most cost effective basis than green roofs.

Social drivers such as provision of recreation and amenity space were seen as the biggest driver for green roofs in the city currently. Although the participants were not convinced that buyers would be willing to pay for the green roof. When the issue of public accessibility was raised participants were concerned about occupational health and safety concerns such as falls and protection from roof mounted infrastructure such as mechanical ventilation systems. Access for people with disabilities was also discussed as a concern with regards to equity. Enhancing rooftop amenity was deemed important with facilities such as benches and seating and coffee carts.

Table 5 summarises the economic, environmental and social concerns with green roof retrofit and demonstrates where the focus groups were aware or not of the issue and secondly, where there was awareness whether they perceived it as positive or negative.

Table 5 Stakeholders and Economic Environmental and Social Aspects of Green Roof Retrofit

\begin{tabular}{|c|c|c|c|}
\hline Aspect & $\begin{array}{l}\text { Identified } \\
(+\mathrm{ve})\end{array}$ & $\begin{array}{l}\text { Identified } \\
\text { (-ve) }\end{array}$ & $\begin{array}{l}\text { Not } \\
\text { identified }\end{array}$ \\
\hline \multicolumn{4}{|l|}{ Economic } \\
\hline Expenses of GR & & $\mathrm{X}$ & \\
\hline A luxury add on & $\sqrt{2}$ & $\mathrm{X}$ & \\
\hline Green Bling & & $\mathrm{X}$ & \\
\hline Quality of lower cost tenders & 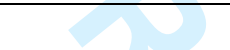 & $\mathrm{X}$ & \\
\hline Maintenance costs & & $\mathrm{X}$ & \\
\hline Whole life cost approach & 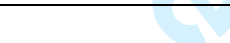 & $\bar{c}$ & $\mathrm{X}$ \\
\hline \multicolumn{4}{|l|}{ Environmental } \\
\hline Bio-diversity (housing rats etc) & & $\mathrm{X}$ & \\
\hline UHI & & $\mathrm{X}$ & \\
\hline Thermal & & & $\mathrm{X}$ \\
\hline Food production & & $\mathrm{X}$ & \\
\hline Carbon sequestration & & & $\mathrm{X}$ \\
\hline Stormwater attenuation & & & $\mathrm{X}$ \\
\hline Improved air quality & & & $\mathrm{X}$ \\
\hline \multicolumn{4}{|l|}{ Social } \\
\hline Amenity space & $\mathrm{X}$ & & \\
\hline OHS issues and risks & & $\mathrm{X}$ & \\
\hline Accessibility for mobility impaired & & $\mathrm{X}$ & \\
\hline $\begin{array}{l}\text { Biophilia missed off / positive health } \\
\text { missed }\end{array}$ & & & $\mathrm{X}$ \\
\hline
\end{tabular}




\section{Conclusions}

This study posed the questions; what are the perceived technical issues stakeholders and built environment professionals need to consider with green roof retrofit for stormwater attenuation? The literature has shown that the key technical issues are position and location of the building, orientation of the roof and amount of overshadowing (if any). The roof type is important in terms of load bearing capacity, size and pitch / slope to accommodate a retrofitted green roof. Surveyors and designers need to consider the existing drainage and waterproofing system, as well as the condition of the existing membrane. If the roof is to be accessible to occupants and building users, access to the roof needs evaluating, also for the construction of the green roof. The weight of substrates and planting needs to be considered in respect of the load bearing capacity of the roof. Availability of a roof top water supply and the type of irrigation system required is a further consideration. Allied to this is the level of maintenance the roof will have and the preferred planting to accommodate this.

Focus groups revealed the key concerns and issues and show that some, but not all issues are typically considered. Overall there was a reasonable level of awareness of the technical issues though further training and up-skilling is needed particularly in the retrofit aspects. This is not surprising as the number of retrofitted green roofs in Sydney is very small but needs to be addressed if the roofs that do undergo retrofit are specified and constructed to standards that will deliver durability and longevity.

The second question; what is the perceived awareness of the economic, social and environmental aspects of green roof retrofit? Here, the economic awareness of the focus group participants showed caution with respect to green roofs, which were seen as expensive and not necessarily cost effective compared to other measures. However there was no mention of whole life cycle costing approaches which would bring in other considerations and allow a more holistic evaluation of the value of the green roof to be taken into account. Where a lower cost tender was concerned there would be concerns over quality of the materials and workmanship, but this is true of all construction tenders and not just a green roof retrofit issue. Further the value of the measure may not be seen, if other social and environmental aspects are not taken into account. In terms of awareness of the environmental aspects of green roof it appears that some, but not all measures are apparent to participants such as improved air quality, stormwater attenuation and carbon sequestration. Further some environmental aspects were perceived in a negative way, as housing rats or not being within the remit of the individual property / property owner i.e. contributing to the potential reduction in urban heat island. The social benefit of access to recreation and amenity space was raised but not in the context of improved well-being and health associated with proximity to nature or the bio-philia effect, furthermore the focus shifted to the risks arising with occupational health and safety and accessibility for those with mobility impairments. Whilst these issues do need consideration and resolution, it seems if there is not an awareness of the real social benefits that accrue from green roofs, the much needed 'champions' which were identified in the focus groups may be insufficient to fulfil the potential demand for such retrofit installations. Further research to better understand the overall costs and benefits of retrofit taking into account the short term and longer term (whole life costing) issues as well as recognising the tangible and intangible benefits of these schemes is pursued. This could lead to the development of a holistic decision making tool for property owners and building professionals in respect of green roof retrofit.

In conclusion there is a need to increase the level of awareness, knowledge and understanding of green roof retrofit of practitioners involved in the maintenance and refurbishment of buildings. The professional bodies have a role to play with the provision of best practice guidelines and notes for members so that they are able to learn about the technical issues and factors to take into account in decision making. There is a need to engage with academics and practitioners from other disciplines such as entomologists and horticulturalists to arrive at optimum design solutions for green roof retrofits. Finally there is a need to further empirical research based on performance monitoring and evaluation of green roofs in different countries. What is clear; is that what works in Europe in terms of thermal or stormwater performance is different in a country like Australia which experiences quite different climatic conditions. With a clear understanding of what is going to work, then the design goals are more likely to be delivered and our experiences of green roof retrofit will be positive. It is recommended that teaching and learning with respect to green roof retrofit is considered in undergraduate and post graduate education and curriculum design in the built environment. Equally provision in the technical colleges is needed so that building contractors have the skills to retrofit green roofs. 
This research was funded partially by the RICS Research Trust project and also by the City of Sydney.

\section{References}

Andras, 2010. Green Roofs: Extensive and intensive flat green roof structures. http://iti.vgtu.lt/sure/Media/Default/Supplementary information/Roger4Students/GreenRoofs.pdf Retreived 29th April 2014.

Blanc, J., Arthur, S. \& Wright, G. 2012. Natural flood management (NFM) knowledge system: Part 1 Sustainable urban drainage systems (SUDS) and flood management in urban areas - Final Report. CREW - Scotland's Centre of Expertise for Waters.

Castleton, H.F., Stovin, V., Beck, S.B.M., and Davidson, J.B. 2010. Green roofs; building energy savings and the potential for retrofit. Energy and Buildings. Vol 42. Pp 1582-1591.

Charlesworth, S. and Warwick, F. (2011) Adapting to and mitigating floods using sustainable urban drainage systems. in Lamond, J. E., Proverbs, D. G., Booth, C. A. and Hammond, F. N. (eds.) Flood hazards, impacts and responses for the built environment. New York: Taylor CRC press.

Czemiel-Berndtsson, J. 2010. Green roof performance towards management of runoff water quantity and quality: A review. Ecological Engineering, 36, 351-360.

Dunnett, N., and Kingsbury, N., 2004. Planting Green Roofs and Living Walls. Timber Press, Portland Oregon.

Dixon, T. and Eames, M. 2014. Sustainable urban development to 2050: complex transitions in the built environment of cities. In: Dixon, T. et al. eds. Urban Retrofitting for Sustainability: Mapping the Transition to 2050. Abingdon: Routledge, pp. 19-47

Environmental Services - City of Portland (2006) Downspout disconnection. 2013 Portland, Oregon USA: City of Portland.

Environmental Services - City of Portland (2011) Portland's Ecoroof Program [online]. Available at: $<$ http://www.portlandoregon.gov/bes/article/261074>.

Fioretti, R., et al., 2010. Green roof energy and water related performance in the Mediterranean climate. Building and Environment, 45(8): p. 1890-1904.

Getter, K. L., Rowe, D. B. \& Andresen, J. A. 2007. Quantifying the effect of slope on extensive green roof stormwater retention. Ecological Engineering, 31, 225-231.

Getter, K.L., Rowe, D. B., and Cregg, B.M., 2009. Solar radiation intensity influences extensive green roof plant communities. Urban Forestry and Urban Greening. Vol 8, issue 4, pp269-281

GreenBuildings.Com 2014. http://www.green-buildings.com/content/78335-green-roof-cost Retrieved 28th April 2014.

IPCC 2013. Xx

Jha, A., Lamond, J., Bloch, R., Bhattacharya, N., Lopez, A., Papachristodoulou, N., Bird, A., Proverbs, D., Davies, J. \& Barker, R. 2011. Five Feet High and Rising - Cities and Flooding in the 21st Century. Policy Research Working Paper 5648. Washington: The World Bank.

Joseph, R., Proverbs, D.G., Lamond, J. and Wassell, P. (2012) Towards the development of a comprehensive systematic quantification of the costs and benefits of property level flood risk adaptation. in Proverbs, D. G., Mambretti, S., Brebbia, C. A. and De Wrachien, D. (eds.) Flood Recovery Innovation and Response III. Southampton: WIT Press, pp.193-205.

Kelly, J., Morledge, R., and Wilkinson, S (eds) 2002. Best Value in Construction RICS/Blackwells ISBN 0632056118.

Kelly, M.J., 2008. Britain's Building Stock. A Carbon Challenge. http://www.lcmp.eng.cam.ac.uk/wpcontent/uploads/081012_kelly.pdf

Koehler, M,. 2003. Plant survival research and bio-diversity; lessons from Europe. Greening rooftops for sustainable communities, Chicago pp313-322. 
Lamond, J. and Proverbs, D. (2009) Resilience to flooding: learning the lessons from an international comparison of the barriers to implementation. Urban Design and Planning, 162(2), pp.63-70

Lamond, J. E., Wilkinson, S. \& Rose, C. 2014 Conceptualising the benefits of green roof technology for commercial real estate owners and occupiers. Pacific Rim Real Estate Conference. PRRES.

MacIvor, J.S. and Lundholm. J, 2011. Performance evaluation of native plants suited to extensive green roof conditions in a maritime climate. Ecological Engineering, 37(3): p. 407-417.

Mentens, J. (n.d.). Green roofs as a tool for solving the rainwater runoff problem in the urbanized 21st century? Landscape and Planning, 217-266.

NYC Environmental Protection (2011) NYC Green Infrastructure Plan, 2011 Update. New YorK: New York City Department of Environmental Protection / New York City Department of Buildings.

NYC Environmental Protection (2012) Guidelines for the Design and Construction of Stormwater Management Systems. New York: New York City Department of Environmental Protection / New York City Department of Buildings.Porsche, U. \& Köhler, M. 2003. Life cycle costs of green roofs - A Comparison of Germany, USA, and Brazil. RIO 3 - World Climate \& Energy Event. Rio de Janeiro, Brazil.

Silverman, D, 2013. $4^{\text {th }}$ Ed. Doing Qualitative Research: A Practical Handbook. Sage Publications.

Stovin, V., Dunnett, N., Hallam, A., 2007. Green roofs - getting sustainable drainage off the ground, in the $6^{\text {th }}$ International Conference of Sustainable Techniques and Strategies in Urban Water Management (Novatech, 2007), Lyon France. Pp 11-18.

Stovin, V., Vesuviano, G. \& Kasmin, H. 2012. The hydrological performance of a green roof test bed under UK climatic conditions. Journal of Hydrology, 414-415, 148-161.

University of Florida 2008. Green roofs/ecoroofs. Florida Field Guide to Low Inmpact Development. Gainesville, FL: University of Florida.

Weiler, S. K. \& Scholz-Barth, K., 2009. Green Roof Systems: A Guide to the Planning, Design, and Construction of Landscapes over Structure. Wiley \& Sons, ISBN: 978-0-471-67495-5.

Wheater, H. \& Evans, E. 2009. Land use, water management and future flood risk. Land Use Policy, 26, S251-S264.

White, I. \& Howe, J. 2002. Flooding and the role of planning in England and Wales: a critical review. Journal of Environmental Planning and Management, 45, 735-745.

Wilkinson S. J. and Reed R. 2009. Green Roof Retrofit Potential in the Central Business District. Journal of Property Management. ISSN 0263-7472. Issue 27 Vol. 5.

Willmot Dixon 2010. Green Roofs. http://www.willmottdixongroup.co.uk/assets/b/r/briefing-note-2green-roofs-ad-approved-270110.pdf Retrieved 29th April 2014.

Williams, N.S.G., Raynor, J.P., and Raynor K.T., 2010 Green roofs for a wide brown land. Opportunities and barriers for rooftop greening in Australia. Urban Forestry and Urban Greening.

Low Impact Urban Design and Development http://www.ourfuture.net.nz/Collections/13 . Retrieved 3rd September 2014. 
Appendix 1 - Focus Group discussion guide

\begin{tabular}{|c|c|}
\hline \multicolumn{2}{|l|}{ Part 1 of session: 50 mins } \\
\hline $\begin{array}{l}\text { Introduction to research and purpose of the focus groups } \\
\text { - } \quad \text { Definition of GR and/or GW infrastructure } \\
\text { - } \quad \text { Where the research fits into the City's wider Strategy }\end{array}$ & 10 mins \\
\hline Participant introductions & 5 mins \\
\hline $\begin{array}{l}\text { 1. What are the key considerations (barriers and opportunities) in design and } \\
\text { construction? }\end{array}$ & 10 mins \\
\hline $\begin{array}{l}\text { 2. What are the key considerations (barriers and opportunities) in property } \\
\text { management and maintenance? }\end{array}$ & 10 mins \\
\hline $\begin{array}{l}\text { W. What are the key considerations (barriers and opportunities) in property marketing } \\
\text { (ie achieving property sales/tenancies - for both commercial and residential property?) }\end{array}$ & 10 mins \\
\hline $\begin{array}{l}\text { Introduce continuum exercise before break - to lead in to next part of the discussion } \\
3 \text { x policy approaches: } \\
\text { (1) incentivisation (financial or otherwise) } \\
\text { (2) pilot projects; } \\
\text { (3) mandation through policy }\end{array}$ & 5 mins \\
\hline \multicolumn{2}{|l|}{5 minute refreshment break \& continuum exercise on whiteboard } \\
\hline \multicolumn{2}{|l|}{ Part 2 of session: 60 mins } \\
\hline $\begin{array}{l}\text { 4. What are the key social, environmental or economic barriers and drivers for GR } \\
\text { and/or GW projects? } \\
\text { - } \\
\text { Environmental drivers (eg biodiversity/food production/UHI effect?) } \\
\text { perceptions } \\
\text { - In your experience, what have people highlighted as reasons they like or dislike GRs } \\
\text { and/or GWs and what are the characteristics of GRs and/or GWs that the general } \\
\text { community sees as most important? } \\
\text { - Which groups do you see as being most likely to value living / working in a locality } \\
\text { where there are GRs and/or GWs? } \\
\text { - Economic/market drivers (Marketability? Investment potential? Attractiveness to } \\
\text { tenants? }\end{array}$ & $\begin{array}{l}30 \text { mins } \\
(10 \text { mins }) \\
(10 \text { mins })\end{array}$ \\
\hline $\begin{array}{l}\text { 5. Future CoS policy approaches: What could the City of Sydney do to promote } \\
\text { inclusion of GRs and/or GWs in new buildings and through retrofits? } \\
\text { - } \quad \text { Incentivisation - eg rebates, grants, FSR bonuses } \\
\text { - } \quad \text { Pilot projects - including on public buildings \& funded for private buildings } \\
\text { - } \quad \text { Regulation - eg mandating inclusion of infrastructure }\end{array}$ & 25 mins \\
\hline $\begin{array}{l}\text { Thank you and wrap-up (project next steps } \& \text { opportunity to give further feedback } \\
\text { by phone/email) }\end{array}$ & 5 mins \\
\hline
\end{tabular}

